\title{
Inhibition of airway smooth muscle tone by Chinese herbal medicines
}

\author{
E. Tagaya, J. Tamaoki, K. Kawatani, M. Taira, A. Nagai
}

\begin{abstract}
Inhibition of airway smooth muscle tone by Chinese herbal medicines. E. Tagaya, J. Tamaoki, K. Kawatani, M. Taira, A. Nagai. C) ERS Journals Ltd 2000.

ABSTRACT: The aim of the present study was to elucidate whether Chinese traditional herbal drugs, Gorei-San (TJ-17) and Toki-Shakuyaku-San (TJ-23), affect airway smooth muscle tone and, if so, to determine what the mechanism of action is.

Rabbit tracheal segments were isolated and the contractile responses to electrical field stimulation and acetylcholine were measured before and after the application of TJ-17 or TJ-23 under isometric conditions in vitro. Ouabain-sensitive rubidium-86 $\left({ }^{86} \mathrm{Rb}\right)$ uptake by tissues in response to each drug was also measured.

Each herbal medicine attenuated the contractile responses to electrical field stimulation and acetylcholine in a concentration-dependent manner, the maximal inhibition of acetylcholine-induced contraction being $37.5 \pm 4.9 \%$ for $\mathrm{TJ}-17$ and $42.4 \pm 5.3 \%$ for $\mathrm{TJ}-23$ ( $\mathrm{p}<0.05$ for each). These effects were not altered by mechanical removal of the epithelium, indomethacin, the nitric oxide synthase inhibitor $N^{G}$-nitroL-arginine methyl ester, the cyclic adenosine monophosphate (cAMP)-dependent protein kinase inhibitor adenosine $3^{\prime} 5^{\prime}$-cyclic monophosphorothiioate (Rp-cAMPS), the cyclic guanosine monophosphate (cGMP)-dependent protein kinase inhibitor KT5823, or the calcium $\left(\mathrm{Ca}^{2+}\right)$-activated potassium $\left(\mathrm{K}^{+}\right)$channel inhibitor charybdotoxin, but were greatly inhibited in the presence of the sodium $\left(\mathrm{Na}^{+}\right)-\mathrm{K}^{+}$adenosine triphosphatase (ATPase) inhibitor ouabain. Incubation of tissues with TJ-17 and TJ23 dose dependently increased ouabain-sensitive ${ }^{86} \mathrm{Rb}$ uptake.

The results of the study suggest that both Gorei-San and Toki-Shakuyaku-San reduce airway smooth muscle tone via a postjunctional mechanism probably through stimulation of the sodium pump and the subsequent hyperpolarization/repolarization of the cell membrane. These effects may contribute to the antiasthmatic properties of these herbal medicines.
\end{abstract}

Eur Respir J 2000; 16: 1123-1128.

First Dept of Medicine, Tokyo Women's Medical University School of Medicine, Tokyo, Japan.

Correspondence: A. Nagai

First Dept of Medicine

Tokyo Women's Medical University School of Medicine

8-1 Kawada-Cho

Shinjuku

Tokyo 162-8666

Japan

Fax: 81353795457

Keywords: Acetylcholine

asthma

bronchoconstriction

ouabain

sodium-potassium adenosine triphosphate

Received: March 72000

Accepted after revision September 132000

This work was supported in part by Grantin-Aid No. 06670632 from the Ministry of Education, Science and Culture, Japan.

Chinese traditional herbal drugs have long been used in the treatment of asthma in Asian countries. Among them, Gorei-San (TJ-17) and Toki-Shakuyaku-San (TJ-23) produce improvements in asthma symptom scores and pulmonary function tests in adult and childhood asthma [1, 2]. Furthermore, long-term administration of these drugs reduce the use of supplemental $\beta_{2}$-agonist in steroiddependent asthma [3]. The mechanisms for the efficacy include inhibition of immunoglobulin-E (IgE)-mediated release of histamine from basophils [4] and plateletactivating factor from neutrophils [5] and prevention of down-regulation of glucocorticoid and $\beta$-adrenergic receptor [5]. However, the direct action on airway smooth muscle tone remains unknown.

The sarcolemmal sodium-potassium adenosine triphosphatase $\left(\mathrm{Na}^{+}-\mathrm{K}^{+}\right.$ATPase $)$has been implicated in the mechanism of relaxant responses of airway and vascular smooth muscle induced by a $\beta$-adrenergic agonist and sodium nitroprusside [6,7]. Stimulation of enzymatic activity of $\mathrm{Na}^{+}-\mathrm{K}^{+}$ATPase may lead to generation of the sodium gradient necessary to exclude calcium $\left(\mathrm{Ca}^{2+}\right)$ via the $\mathrm{Na}^{+} / \mathrm{Ca}^{+}$exchange or hyperpolarization of the membrane, which in turn reduces $\mathrm{Ca}^{2+}$ influx through mem- brane potential-dependent $\mathrm{Ca}^{2+}$ channels [8]. It has recently been shown that TJ-17 and TJ-23 protect brain cells against apoptosis by elevating $\mathrm{Na}^{+}-\mathrm{K}^{+}$ATPase activity of microvascular beds [9]. Therefore, it was hypothesized that if these drugs could stimulate sarcolemmal $\mathrm{Na}^{+}-\mathrm{K}^{+}$ATPase in airway smooth muscle cells, then bronchodilation might occur through the inhibition of $\mathrm{Ca}^{2+}$-dependent contraction of airway smooth muscle cells. To test this hypothesis, the effects of these agents on rabbit tracheal segments under isometric conditions were examined in vitro.

\section{Material and methods}

\section{Preparation of tissues}

Japanese-white rabbits of either sex, weighing 1.7-2.4 $\mathrm{kg}$, were anaesthetized with pentobarbital sodium (35 $\mathrm{mg} \cdot \mathrm{kg}^{-1}, i . v$.), and the trachea was removed and immersed in oxygenated Krebs-Henseleit $(\mathrm{KH})$ solution consisting of the following $(\mathrm{mM})$ : sodium chloride $(\mathrm{NaCl}), 118$; potassium chloride $(\mathrm{KCl})$, 5.9; calcium chloride $\left(\mathrm{CaCl}_{2}\right)$, 
2.5; magnesium sulphate $\left(\mathrm{MgSO}_{4}\right), 1.2 ;$ monosodium phosphate $\left(\mathrm{NaH}_{2} \mathrm{PO}_{4}\right), 1.2$; sodium bicarbonate $(\mathrm{NaH}-$ $\mathrm{CO}_{3}$ ), 25.5; and D-glucose, 5.6. Rings of the trachea were dissected free of loose connective tissue and mounted in organ chambers filled with $14 \mathrm{~mL}$ of $\mathrm{KH}$ solution maintained at $37^{\circ} \mathrm{C}$ and continuously aerated with a gas mixture of $94 \%$ oxygen $\left(\mathrm{O}_{2}\right)-6 \%$ carbon dioxide $\left(\mathrm{CO}_{2}\right)$ to obtain a $\mathrm{pH}$ of 7.4 , a partial pressure of carbon dioxide $\left(\mathrm{PCO}_{2}\right)$ of $38 \mathrm{Torr}$, and a partial pressure of oxygen $\left(\mathrm{PO}_{2}\right)$ of $>500$ Torr. The lower end of the tracheal ring was attached to a glass hook at the base of the organ chamber by a loop of silk thread, and the upper end was attached in the same manner to a force-displacement transducer (Nihon Kohden, JB-652T, Tokyo, Japan) for continuous recording of isometric tension by a pen recorder (Nihon Kohden, WT685G).

Each organ chamber was fitted with two rectangular platinum electrodes $(6 \times 25 \mathrm{~mm})$ placed alongside the tissue for transmural electrical field stimulation (EFS: biphasic square-wave, 1-ms pulse duration, supramaximal voltage of $40 \mathrm{~V}$ for $15 \mathrm{~s}$ ). In a preliminary study, the contractile responses of rabbit tracheal rings to EFS (1$50 \mathrm{~Hz})$ were abolished by atropine $\left(1 \times 10^{-6} \mathrm{M}\right)$ and were therefore, cholinergic in nature. The tissues were allowed to equilibrate in the bath for $60 \mathrm{~min}$, while they were washed with $\mathrm{KH}$ solution every $15 \mathrm{~min}$ and the resting tension was adjusted to a value that gave the maximal contractile response to acetylcholine. Separate experiments on the relationship between resting tension and active tension showed maximal responses with $4 \mathrm{~g}$ of resting tension. A contractile response was measured as the difference between peak tension developed and resting tension.

\section{Effects on EFS- and acetylcholine-induced contraction}

TJ-17 and TJ-23 were assessed for their affect on neurally-mediated smooth muscle contraction, by determining contractile responses to EFS before and after the addition of the drugs $\left(100 \mu \mathrm{g} \cdot \mathrm{mL}^{-1}\right)$. The control responses to EFS were first obtained at increasing frequencies of stimulation (1-50 Hz); each drug was added to the chamber, and after a 15-min incubation the measurements were repeated; the EFS-induced contraction before (control) and after the drug addition were then compared. In a preliminary study carried out by the authors, addition of the solvent (KH solution) alone had no effect on the contractile responses to EFS. Moreover, this incubation period was chosen because in the separate experiment the EFS (10 $\mathrm{Hz}$ )-induced contraction was determined at $1,5,15$, and 45 min after the addition of TJ-17 or TJ-23, and it was found that the inhibition of the contraction reached a plateau at $15 \mathrm{~min}$ for each drug.

In order to identify whether the site of drug action is pre- or postjunctional in the cholinergic motor pathway, the effect on the contractile responses to exogenously applied acetylcholine $\left(1 \times 10^{-8}-1 \times 10^{-3} \mathrm{M}\right)$ was also examined. After establishing the first concentration-response curves, tissues were washed with $\mathrm{KH}$ solution until the tension returned to the resting levels. Then, TJ-17 or TJ-23 $\left(100 \mu \mathrm{g} \cdot \mathrm{mL}^{-1}\right)$ was added, the second concentrationresponse curves for acetylcholine were generated $15 \mathrm{~min}$ later, and the contractile responses to acetylcholine before (control) and after the drug addition were compared.

To determine the concentration-dependent effects of TJ-17 and TJ-23, contractile responses to acetylcholine at a concentration that produced approximately $50 \%$ of the control maximum contraction $\left(1 \times 10^{-5} \mathrm{M}\right)$ were measured 15 min after the addition of various concentrations of each drug $\left(1-1,000 \mu \mathrm{g} \cdot \mathrm{mL}^{-1}\right)$. In this experiment, TJ-17 or TJ23 was cumulatively added after establishing the effect of each concentration.

Effects of epithelial removal and pharmacologic blocking agents

To test whether the release of epithelium-derived relaxing factor is involved in the effects of TJ-17 and TJ-23 [10], the effects of the drug $\left(100 \mu \mathrm{g} \cdot \mathrm{mL}^{-1}\right)$ on acetylcholine $\left(1 \times 10^{-5} \mathrm{M}\right)$-induced contractions between epithelium-intact tissues and the tissues with their epithelial layer removed were compared. To do so, the epithelial cells were gently removed by passage of a moistened cotton-wrapped pipe cleaner through the tracheal lumen, and the absence of the epithelial layer was confirmed after the experiment by staining tissues with Masson's trichrome.

The involvement of the activation of $\mathrm{Na}^{+}-\mathrm{K}^{+}$ATPase [11] and the opening of $\mathrm{Ca}^{2+}$-activated $\mathrm{K}$ channel [12] was assessed by determining the inhibition of the contractile responses to acetylcholine $\left(1 \times 10^{-5} \mathrm{M}\right)$ induced by TJ-17 and TJ-23 (100 $\left.\mu \mathrm{g} \cdot \mathrm{mL}^{-1}\right)$ in the absence and presence of ouabain $\left(1 \times 10^{-7} \mathrm{M}\right)$, a Na ${ }^{+}-\mathrm{K}^{+}$-ATPase inhibitor, or charybdotoxin $\left(1 \times 10^{-7} \mathrm{M}\right), \mathrm{a} \mathrm{Ca}^{2+}$-activated $\mathrm{K}^{+}$ channel blocker [13]. In addition, possible involvement of the generation of inhibitory prostaglandins [14], the release of nitric oxide [15], and the synthesis of cyclic adenosine monophosphate (cAMP) and cyclic guanosine monophosphate (cGMP) were likewise assessed by the use of the following pharmacological blocking agents: indomethacin $\left(3 \times 10^{-6} \mathrm{M}\right)$, a cyclooxygenase inhibitor; $N^{\mathrm{G}}$-nitro-L-arginine methyl ester (L-NAME, $1 \times 10^{-3} \mathrm{M}$ ), an inhibitor of nitric oxide synthase [16]; adenosine $3^{\prime}, 5^{\prime}$ cyclic monophosphorothioate (Rp-cAMPS, $\left.1 \times 10^{-4} \mathrm{M}\right)$, a specific inhibitor of cAMP-dependent protein kinase; and KT5823 ( $N$-methyl-(8R*, 9S*, 11S*)-(-)-9-methoxycarbonyl-8-methyl-2,3,9,10-tetrahydro-8,11-epoxy-1H,8H, $11 \mathrm{H}-2,7 \mathrm{~b}, 11 \mathrm{a}-$ triazadibenzo(a,g)cycloocta(cde) trinden-1one, $2 \times 10^{-6} \mathrm{M}$ ), a specific inhibitor of cGMP-dependent protein kinase [17].

\section{Measurement of $\mathrm{Na}^{+}-\mathrm{K}^{+}$-ATPase activity}

To examine the effects of $\mathrm{TJ}-17$ and $\mathrm{TJ} 23$ on sarcolemmal sodium pump activity, ouabain-sensitive ${ }^{86} \mathrm{Rb}$ uptake by epithelium-denuded tracheal rings was measured. After incubation of the tissues for $15 \mathrm{~min}$ with various concentrations of each drug $\left(1-1,000 \mu \mathrm{g} \cdot \mathrm{mL}^{-1}\right)$, rubidium- 86 chloride $\left({ }^{86} \mathrm{RbCl}\right)\left(2 \mu \mathrm{Ci} \cdot \mathrm{mL}^{-1}\right)$ was added, and $10 \mathrm{~min}$ later the tissues were washed with ice-cold unlabelled $\mathrm{KH}$ solution to remove the radioisotope from the extracellular compartment. The tissues were then blotted on a filter paper, placed in a plastic vial, dried overnight in an oven at $100^{\circ} \mathrm{C}$, and the ${ }^{86} \mathrm{Rb}$ contents were 
determined by gamma counting. To determine ouabainsensitive ${ }^{86} \mathrm{Rb}$ uptake, the maximally effective concentration of ouabain $\left(2 \times 10^{-4} \mathrm{M}\right)$ was added $10 \mathrm{~min}$ before the introduction of ${ }^{86} \mathrm{RbCl}$ into the medium. The ouabainsensitive portion of the ${ }^{86} \mathrm{Rb}$ uptake, an index of sodium pump activity [18], was calculated by subtracting the ouabain-insensitive ${ }^{86} \mathrm{Rb}$ uptake from the total ${ }^{86} \mathrm{Rb}$ uptake, and the data were expressed as nmol. $\mathrm{min}^{-1}$ per $\mathrm{mg}$ of tissue dry weight.

\section{Drugs}

The following drugs were used: acetylcholine chloride, indomethacin, ouabain, L-NAME (Sigma Chemical Co., St. Louis, MO, USA); charybdotoxin (Peptide Institute Ltd., Osaka, Japan); and Rp-cAMPS (BIOLOG Life Science Institute, Bremen, Germany). KT 5823 was a gift from Kamiya Biomedical Company (Thousand Oaks, CA, USA). TJ-17 and TJ-23 were obtained from Tsumura Co. (Tokyo, Japan). ${ }^{86} \mathrm{RbCl}$ was obtained from Amersham (Tokyo, Japan). Indomethacin was dissolved in absolute ethanol at $1 \times 10^{-2} \mathrm{M}$ and subsequently diluted in $\mathrm{KH}$ solution, and other drugs were dissolved in $\mathrm{KH}$ solution. Working solutions of all drugs were kept on ice and added to the organ chamber in $140-\mu \mathrm{L}$ aliquots.

\section{Statistical analysis}

All values were expressed as mean \pm SEM. Statistical analysis was performed by ANOVA followed by either Turkey's test for multiple comparison or by a paired ttest, and a p-value of $<0.05$ was considered statistically significant.

\section{Results}

\section{Contractile responses of tracheal segments}

Addition of TJ-17 and TJ-23 at concentrations used in the present experiments did not alter the resting tension of rabbit tracheal segments. However, as demonstrated in figure 1, incubation of tissues for $15 \mathrm{~min}$ with each drug at a concentration of $100 \mu \mathrm{g} \cdot \mathrm{mL}^{-1}$ significantly reduced the contractile responses to EFS at almost all the stimulus frequencies, so that the frequency-contractile response curves were displaced to the right.

Both TJ-17 and TJ-23 $\left(100 \mu \mathrm{g} \cdot \mathrm{mL}^{-1}\right)$ also attenuated the acetylcholine-induced contraction (fig. 2). The inhibitory effects of TJ-17 and TJ-23 on the acetylcholine $\left(1 \times 10^{-5}\right.$ $\mathrm{M})$-induced contraction were concentration-dependent, the maximal inhibition being $37.5 \pm 4.9 \%$ for TJ-17 ( $\mathrm{p}<$ $0.05, \mathrm{n}=6)$ and $42.4 \pm 5.3 \%$ for $\mathrm{TJ}-23(\mathrm{p}<0.05, \mathrm{n}=6)$ observed at a concentration of $1,000 \mu \mathrm{g} \cdot \mathrm{mL}^{-1}$ (fig. 3a).

\section{Effects of epithelial removal and pharmacological blocking agents}

Incubation of the tissues whose epithelial cells had been mechanically removed for 15 min with TJ-17 and TJ-23 $\left(100 \mu \mathrm{g} \cdot \mathrm{mL}^{-1}\right)$ reduced the contractile responses to acetylcholine $\left(1 \times 10^{-5} \mathrm{M}\right)$, where the magnitude of inhibition
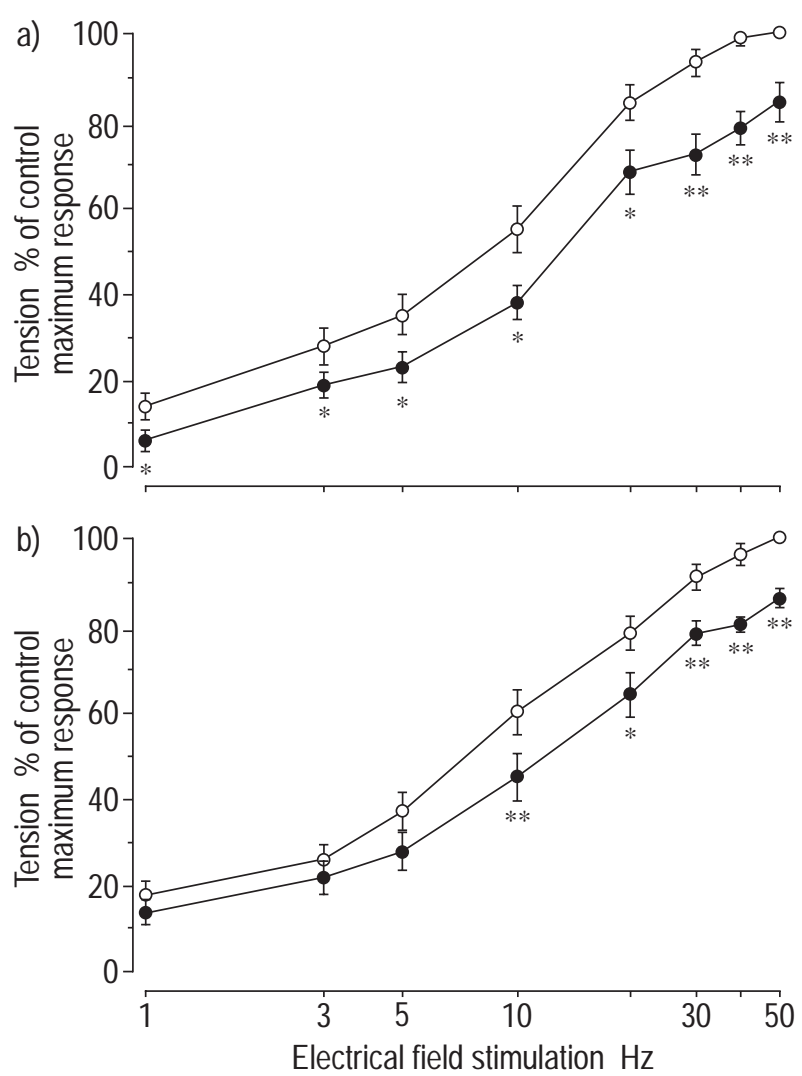

Fig. 1. - a) Effects of Gorei-San (TJ-17) and b) Toki-Shakuyaku-San on contractile responses of rabbit tracheal segments to electrical field stimulation. After measuring control responses to increasing stimulus frequencies $(\bigcirc), \mathrm{TJ}-17$ or TJ-23 at $100 \mu \mathrm{g} \cdot \mathrm{mL}^{-1}$ was added, and $15 \mathrm{~min}$ later the measurements were repeated $(\mathbf{O})$. Values are expressed as percent of the maximal baseline response. Data are mean \pm SEM; $n=8$ for each point. *: $\mathrm{p}<0.05 ; * *: \mathrm{p}<0.01$; significantly different from the corresponding control response.

was not significantly different from that observed with epithelium-intact tissues (fig. 3b).

The effects of ouabain and charybdotoxin on the contractile responses to acetylcholine were then examined. As shown in figure 4, pretreatment of tissues with ouabain attenuated the inhibitory effects of TJ-17 and TJ-23 (100 $\left.\mu \mathrm{g} \cdot \mathrm{mL}^{-1}\right)$, the inhibition of acetylcholine $\left(1 \times 10^{-5} \mathrm{M}\right)$ induced contraction being decreased from $31.8 \pm 4.9$ to $12.5 \pm 3.2 \%(\mathrm{p}<0.05, \mathrm{n}=9)$ and from $37.3 \pm 4.6$ to $14.0 \pm$ $4.0 \%(\mathrm{p}<0.05, \mathrm{n}=9)$, respectively. In contrast, pretreatment with charybdotoxin did not alter the effects of TJ-17 and TJ-23. Likewise, other pharmacological blocking agents including indomethacin, L-NAME, Rp-cAMPS, and KT5823 had no effect on the inhibition of acetylcholine $\left(1 \times 10^{-5} \mathrm{M}\right)$-induced contraction by TJ-17 and TJ-23 $\left(100 \mu \mathrm{g} \cdot \mathrm{mL}^{-1}\right)(\mathrm{n}=6-8$ for each, data not shown).

\section{Ouabain-sensitive rubidium-86 uptake}

Incubation of rabbit tracheal segments for 15 min with TJ-17 and TJ-23 increased the ouabain-sensitive portion of the ${ }^{86} \mathrm{Rb}$ uptake, which comprised of $\sim 40 \%$ of the total portion of the ${ }^{86} \mathrm{Rb}$ uptake, in a concentration-dependent manner (fig. 5). The significant responses of ouabainsensitive ${ }^{86} \mathrm{Rb}$ uptake were observed at concentrations of 

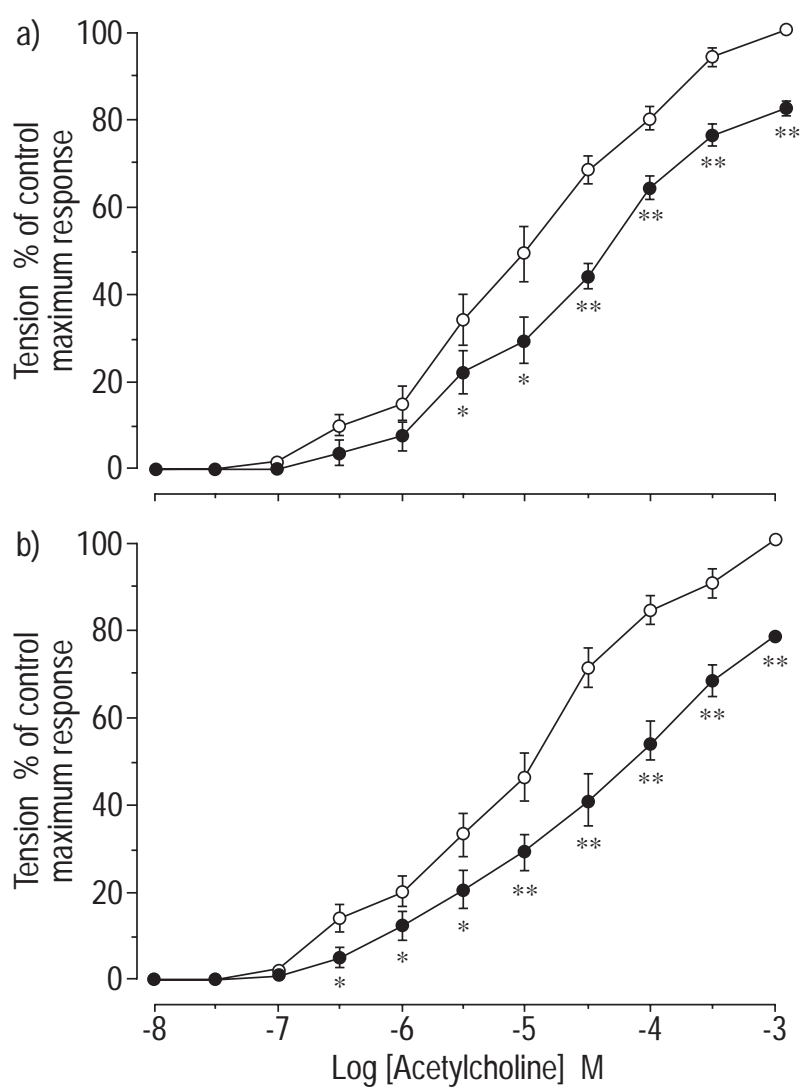

Fig. 2. - a) Effects of Gorei-San (TJ-17) and b) Toki-Shakuyaku-San (TJ-23) on contractile responses to acetylcholine. After establishing the control concentration-response curves for acetylcholine were generated (O), TJ-17 or TJ-23 at $100 \mu \mathrm{g} \cdot \mathrm{mL}^{-1}$ was added, the tissues were washed, and 15 min later the measurements were repeated $(\mathbf{O})$. Values are expressed as percent of the maximal baseline response. Data are mean \pm SEM; $\mathrm{n}=8$ for each point. $*: \mathrm{p}<0.05$; $* *: \mathrm{p}<0.01$; significantly different from the corresponding control response.

$\geq 100 \mu \mathrm{g} \cdot \mathrm{mL}^{-1}$ for each herbal medicine, and 1,000 $\mu \mathrm{g} \cdot \mathrm{mL}^{-1} \mathrm{TJ}-17$ and TJ-23 increased the values from $0.9 \pm 0.3 \mathrm{nmol} \cdot \mathrm{min} \cdot \mathrm{mg}^{-1}$ to $4.7 \pm 0.6 \mathrm{nmol} \cdot \mathrm{min} \cdot \mathrm{mg}^{-1}(\mathrm{p}<$ $0.05, \mathrm{n}=10)$ and to $4.2 \pm 0.7 \mathrm{nmol} \cdot \mathrm{min} \cdot \mathrm{mg}^{-1} \quad(\mathrm{p}<0.05$, $\mathrm{n}=10$ ), respectively.

\section{Discussion}

The in vitro studies demonstrate that the traditional Chinese herbal drugs, TJ-17 and TJ-23, inhibit the contractile responses of rabbit tracheal smooth muscle to EFS and acetylcholine presumably by stimulating the sarcolemmal sodium pump. Thus, these drugs possess a protective action against bronchoconstriction, an effect that could account for the efficacy in the treatment of asthma.

Airway smooth muscle contraction is generally associated with intracellular $\mathrm{Ca}^{2+}$ mobilization and membrane depolarization. The responses induced by EFS and exogenously applied acetylcholine are mediated through prejunctional and postjunctional mechanisms, respectively. In the present study, TJ-17 and TJ-23 attenuated the EFSinduced contraction with the same magnitude as observed with the acetylcholine-induced contraction, implying that the site of action of these drugs is most likely postjunctional. This suggests that TJ-17 and TJ-23 may have

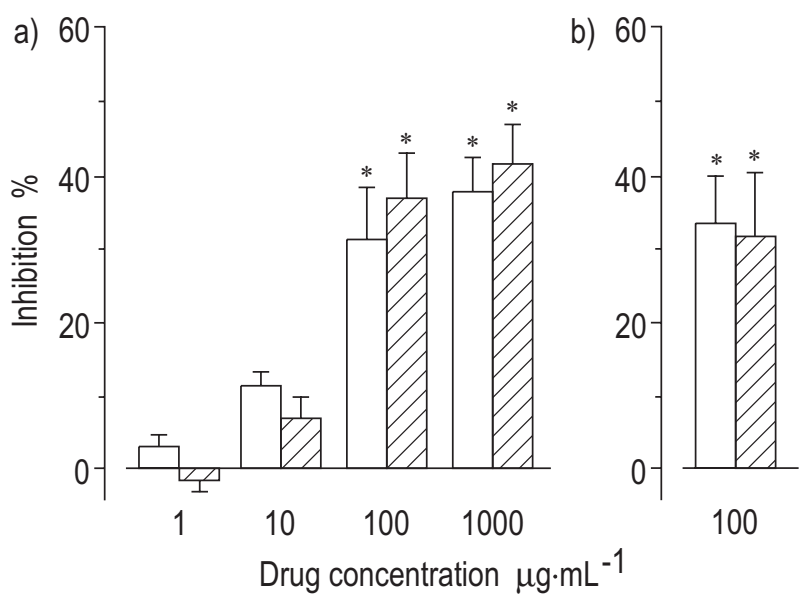

Fig. 3. - Effects of various concentrations of Gorei-San (TJ-17) ( $\square$ ) and Toki-Shakuyaku-San (TJ-23) (ש) on contractile responses to acetylcholine of rabbit tracheal segments whose epithelial cells were a) intact or b) had been mechanically removed. Values are expressed as per cent of the inhibition of acetylcholine $\left(1 \times 10^{-5} \mathrm{M}\right)$-induced contraction. Data are mean \pm SEM; $n=6$ for each column. *: $\mathrm{p}<0.05$, significantly different from the response obtained before the drug addition ( $0 \%$ inhibition).

exerted their effects by directly acting on airway smooth muscle cells rather than by modulating the release of acetylcholine from cholinergic nerve terminals.

There might be several mechanisms by which TJ-17 and TJ-23 inhibited airway contraction. First, airway epithelial cells can inhibit bronchoconstriction through a release of the inhibitory prostaglandins and epithelium-derived relaxing factor [10]. However, because mechanical removal of the epithelium did not alter the effects of TJ-17 and TJ-23, involvement of airway epithelial cells in the drug action seems unlikely. Second, TJ-17 and TJ-23 could have stimulated airway smooth muscle cells to release prostaglandin $E_{2}$ [14], but this possibility is also unlikely because of the lack of effect of indomethacin pretreatment. Third, airway cells such as nerve fibres and epithelial cells are constitutively generating nitric oxide (NO) $[19,20]$, which in turn inhibits bronchoconstrictor

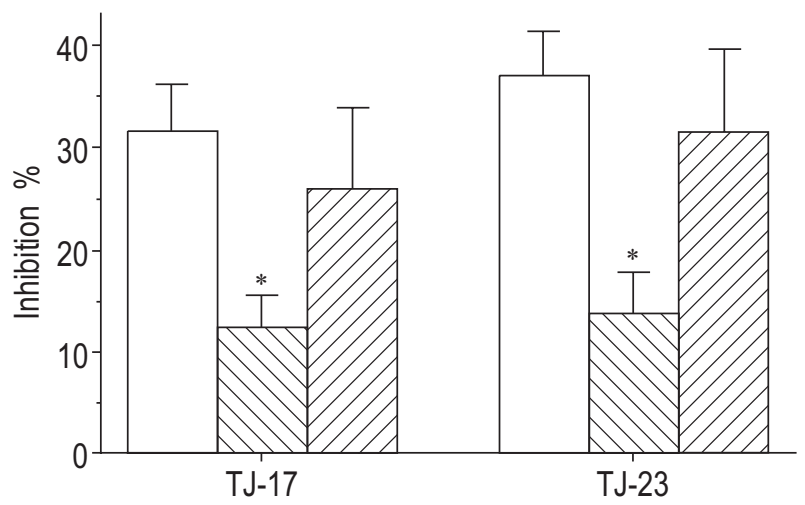

Fig. 4. - Effects of ouabain and charybdotoxin on the inhibition of acetylcholine-induced contraction produced by Gorei-San (TJ-17) and Toki-Shakuyaku-San (TJ-23). The contractile responses to acetylcholine $\left(1 \times 10^{-5} \mathrm{M}\right)$ were determined before and $15 \mathrm{~min}$ after the addition of TJ17 or TJ-23 at $100 \mu \mathrm{g} \cdot \mathrm{mL}^{-1}$ in the absence $(\square)$ and presence of ouabain $\left(1 \times 10^{-7} \mathrm{M},(\mathbb{\mathbb { Q }})\right.$ or charybdotoxin $\left(1 \times 10^{-7} \mathrm{M}, \mathbb{Z}\right)$. Values are expressed as percent of the inhibition of acetylcholine-induced contraction. Data are mean \pm SEM; $n=9$ for each column. $*$ : $\mathrm{p}<0.05$, significantly different from the value for $\mathrm{TJ}-17$ or $\mathrm{TJ}-23$ alone. 


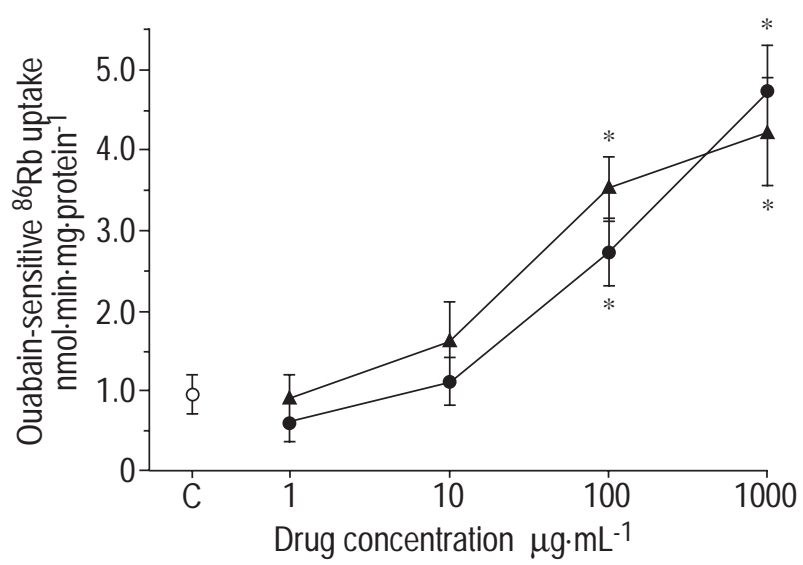

Fig. 5. - Effects of various concentrations of Gorei-San (TJ-17) and Toki-Shakuyaku-San (TJ-23) on ouabain-sensitive rubidium-86-uptake by epithelium-denuded rabbit tracheal segments. Tissues were incubated for $15 \mathrm{~min}$ with Krebs-Henseleit solution (control), TJ-17 (O), or and TJ-23 ( $\mathbf{\Delta})$. Data are mean \pm SEM; $n=10$ for each point. C: control. *: $\mathrm{p}<0.05$, significantly different from the control value.

responses [21]. In the present study, because the effects of TJ-17 and TJ-23 were not altered by the specific nitric oxide synthetase (NOS) inhibitor L-NAME [16], the possibility that the herbal drugs could have stimulated the synthesis and/or release of NO can be excluded. Finally, pretreatment of tissues with Rp-cAMPS, a cAMP-dependent protein kinase inhibitor, or KT5823, a cGMPdependent protein kinase inhibitor [13], had no effect on the TJ-17- and TJ-23-induced inhibition, indicating that the involvement of these cyclic nucleotides is not likely.

There is ample evidence that $\mathrm{Ca}^{2+}$-activated $\mathrm{K}^{+}$channel and $\mathrm{Na}^{+}-\mathrm{K}^{+}$ATPase, an enzyme responsible for the electrochemical gradient of $\mathrm{Na}^{+}$and $\mathrm{K}^{+}$across the cell membrane, are present on airway smooth muscle cells and play an important role in the regulation of the contractility $[7,8]$. The opening of $\mathrm{Ca}^{2+}$-activated $\mathrm{K}^{+}$channels and stimulation of $\mathrm{Na}^{+}-\mathrm{K}^{+}$ATPase activity may reduce smooth muscle contraction by increasing the $\mathrm{Na}^{+} / \mathrm{Ca}^{2+}$ exchange and inhibiting the $\mathrm{Ca}^{2+}$ influx through the membrane potential-dependent $\mathrm{Ca}^{2+}$ channel [22]. In the present study, incubation of tissues with the $\mathrm{Na}^{+}-\mathrm{K}^{+}-$ ATPase inhibitor ouabain substantially attenuated the effects of TJ-17 and TJ-23 on the contractile responses to acetylcholine, whereas prior blockade of $\mathrm{Ca}^{2+}$-activated $\mathrm{K}^{+}$channel by charybdotoxin [13] was without effect. Therefore, the observed effects of the herbal drugs may have derived from the stimulation of $\mathrm{Na}^{+}-\mathrm{K}^{+}$-ATPase activity.

The sensitivity of $\mathrm{Na}^{+}-\mathrm{K}^{+}$-ATPase to ouabain is variable depending on the tissues and animal species [23], and it is uncertain whether the concentration of ouabain used in the contraction studies $\left(1 \times 10^{-7} \mathrm{M}\right)$ is sufficient to completely inhibit this enzyme in rabbit tracheal smooth muscle cells. However, this concentration was chosen because it did not alter the baseline tension and the contractile responses to acetylcholine, and because a previous study showed that $\mathrm{K}^{+}$loss and $\mathrm{Na}^{+}$accumulation were produced by $50 \mathrm{nM}$ ouabain in other tissues [24]. To further support the notion that $\mathrm{Na}^{+}-\mathrm{K}^{+}$-ATPase is involved, ouabain-sensitive ${ }^{86} \mathrm{Rb}$ uptake by tracheal tissues, an index of $\mathrm{Na}^{+}-\mathrm{K}^{+}$-ATPase activity [18], was measured, and it was found that incubation of tissues with
TJ-17 and TJ-23 increased ouabain-sensitive ${ }^{86} \mathrm{Rb}$ uptake in a concentration-dependent manner. Moreover, it should be noted that the concentrations of the herbal drugs required to significantly increase ouabain-sensitive ${ }^{86} \mathrm{Rb}$ uptake $\left(100 \mu \mathrm{g} \cdot \mathrm{mL}^{-1}\right)$ were identical to those observed with the experiment on the acetylcholine-induced contraction. Because the tracheal rings also contain cartilage and connective tissues, ${ }^{86} \mathrm{Rb}$ uptake measured in the present experiment does not necessarily reflect smooth muscle $\mathrm{Na}^{+}-\mathrm{K}^{+}$-ATPase activity. However, there has been no evidence that alterations in $\mathrm{Na}^{+}-\mathrm{K}^{+}$-ATPase activity of cells other than smooth muscle and epithelium affects airway contraction. Thus it is speculated that sarcolemmal $\mathrm{Na}^{+}-\mathrm{K}^{+}$-ATPase may be most probably involved in the effects of TJ-17 and TJ-23.

Chinese traditional medicine generally consists of several ingredients extracted from the roots and nutlets of plants. For example, there are six and seven ingredients in TJ-17 and TJ-23, respectively, where Alismatis rhizoma, Hoelen, and Atractylodis lanceae rhizoma are common constituents of these drugs. Further studies are needed to determine what constituent is responsible for the observed effects of these herbal drugs, and it will be necessary to determine if there are interactions between the constituents.

To conclude, traditional Chinese herbal drugs Gorei-San and Toki-Shakuyaku-San, inhibit airway smooth muscle contraction, thereby probably protecting against bronchoconstriction in asthma. This inhibitory effect may be associated with stimulation of sarcolemmal sodiumpotassium adenosine triphosphatase activity and the consequent membrane hyperpolarization/repolarization of airway smooth muscle cells.

Acknowledgements. The authors would like to thank
M. Shino and Y. Sugimura for their technical assistance.

\section{References}

1. Egashira T, Ushijima M, Yoshioka Y. Blood stagnation in cases of steroid-dependent bronchial asthma. Kampo and Immuno-Allergy 1994; 8: 122-131.

2. Ohgimi Y. Therapeutic effect of Gorei-San on asthmatic attacks in children. Nippon Toyo-Igaku Zasshi 1992; 42: 53-59.

3. Fujiwara J, Nagata T. Role of Kampo drugs in the treatment of chronic severe asthma. Jpn J Primary Care 1982; 5: 285-289.

4. Koda A, Nishihori T, Nagai H, Matsuura T, Tsuchiya H. Anti-allergic actions of crude drugs and blended Chinese traditional medicine: effect on type I and type IV allergic reactions. Folia Pharmacol Japon 1982; 80: 31-41.

5. Miyamoto $T$, Takaishi $T$, Morita $H$, Nuriyama $M$, Nakamura T. The actions of Saiboku-to (TJ-96) on histamine release and the production of platelet-activating factor in human leukocytes. In: Miyamoto $\mathrm{T}$, ed. Medicines of Plant Origin in Modern Therapy. Oxford, Oxford Clinical Communications, 1990; pp. 12-13.

6. Webb RC, Bohr DF. Relaxation of vascular smooth muscle by isoproterenol, dibutyryl-cyclic AMP and theophylline. J Pharmacol Exp Ther 1981; 217: 26-35.

7. Gunst SJ, Stropp JQ. Effect of Na-K-adenosinetriphosphatase activity on relaxation of canine tracheal smooth muscle. J Appl Physiol 1988; 64: 635-641. 
8. Fleming WW. The electrogenic $\mathrm{Na}^{+}, \mathrm{K}^{+}$-pump in smooth muscle: physiologic and pharmacologic significance. Annu Rev Pharmacol Toxicol 1980; 20: 129-149.

9. Hagino H, Kawamata G, Takeishi T, Yamamura S. Effects of extracts from Chinese trees on sodium poum activity in brain vascular endothelial cells. Kampo Igaku 1997; 21: 45-49.

10. Flavahan NA, Aarhus JJ, Rimele TJ, Vanhoutte PM. Respiratory epithelium inhibits bronchial smooth muscle tone. J Appl Physiol 1985; 58: 834-838.

11. Thomas RC. Electrogenic sodium pump in nerve and muscle cells. Physiol Rev 1972; 52: 563-594.

12. Miura M, Belvisi MG, Stretton CD, Yacoub MH, Barnes PJ. Role of potassium channels in bronchodilator responses in human airways. Am Rev Respir Dis 1992; 146: $132-136$.

13. Gimenez-Gallego G, Navia MA, Reuben JP, Katz GM, Kaczorowski GI, Garcia ML. Purification, sequence and model structure of charybdotoxin, a potent selective inhibitor of calcium-activated potassium channels. Proc Natl Acad Sci USA 1988; 85: 3239-3333.

14. Walters EH, O'Byrne PM, Fabbri LM, Graf PD, Holtzman MJ, Nadel JA. Control of neurotransmission by prostaglandins in canine trachealis smooth muscle. $J$ Appl Physiol 1984; 57: 129-134.

15. Tamaoki J, Kondo M, Takemura H, Chiyotani A, Yamawaki I, Konno K. Cyclic AMP-mediated release of nitric oxide from canine cultured tracheal epithelium. Am J Respir Crit Care Med 1995; 152: 1325-1330.

16. Rees DD, Palmer RMJ, Schulz R, Hodson HF, Moncada
S. Characterization of three inhibitors of endothelial nitric oxide synthase in vitro and in vivo. Br J Pharmacol 1990; 101: 746-752.

17. Kase H, Iwahashi K, Nakanishi S, et al. K-252 compounds, novel and potent inhibitors of protein kinase $\mathrm{C}$ and cyclic nucleotide-dependent protein kinases. Biochem Biophys Res Commun 1987; 142: 436-440.

18. Akera T, Yamamoto S, Temma K, Kim D, Brody TA. Is ouabain-sensitive rubidium or potassium uptake a measure of sodium pump activity in isolated cardiac muscle. Biochem Biophys Acta 1981; 640: 779-790.

19. Kannan MS, Johnson DE. Nitric oxide mediates the neural nonadrenergic, noncholinergic relaxation of pig tracheal smooth muscle. Am J Physiol 1992; 262: L511L514.

20. Asano K, Chee CBE, Gaston B, et al. Constitutive and inducible nitric oxide synthase gene expression, regulation, and acativity in human lung epithelial cells. Proc Natl Acad Sci USA 1994; 91: 10089-10093.

21. Moncada S, Palmer RMJ, Higgs EA. Nitric oxide: physiology, pathophysiology, and pharmacology. Pharmacol Rev 1991; 43: 109-142.

22. Clausen $\mathrm{T}$, Nielsen $\mathrm{OB}$. The $\mathrm{Na}^{+}, \mathrm{K}^{+}$-pump and muscle contractility. Acta Physiol Scand 1994; 152: 365-373.

23. Akera T, Brody TM. The role of $\mathrm{Na}^{+}, \mathrm{K}^{+}$-ATPase in the inotropic actions of digitalis. Pharmacol Rev 1978; 29: 187-220.

24. Godfraind T, Ghysel-Burton J. Binding sites related to ouabain-induced stimulation or inhibition of the sodium pump. Nature 1977; 265: 165-166. 